\title{
PENGARUH PROFITABILITAS TERHADAP NILAI PERUSAHAAN PADA PT. MANDALA MULTIFINANCE, Tbk. \\ Oleh :
}

\section{Elvira Palisungan}

Email : elvirapalisungan00@gmail.com

Institut Bisnis dan Keuangan Nitro Makassar

\begin{abstract}
ABSTRAK
Penelitian ini bertujuan untuk mengetahui pengaruh profitabilitas terhadap nilai perusahaan pada perusahaan. Populasi dalam penelitian ini adalah perusahaan sub sektor lembaga pembiayaan yang terdaftar di Bursa Efek Indonesia periode 2018-2020 yang berjumlah populasi sebanyak 19 perusahaan. Penentuan jumlah sampel dalam penelitian ini menggunakan metode purposive sampling, tujuan menggunakan purposive sampling ialah untuk mendapatkan sampel yang representatif sesuai dengan kriteria yang ditentukan peneliti .
\end{abstract}

Kata kunci : profitabilitas, nilai perusahaan

\section{PENDAHULUAN}

Pesatnya perkembangan Bursa Efek Indonesia tidak dapat dipisahkan dari peran investor dalam melakukan transaksi perdagangan di BEI. Sebelum seorang investor memutuskan untuk menginvestasikan dananya di pasar modal, ada kegiatan terpenting yang perlu dilakukan, yaitu penilaian cermat terhadap emiten, ia harus percaya bahwa informasi yang diterimanya adalah informasi yang benar, sistem perdagangan dapat 
dipercaya, serta tidak ada pihak yang memanipulasi informasi dalam perdagangan. (Alamsyah, 2013).Tanpa keyakinan tersebut, pemodal tentunya tidak akan bersedia membeli sekuritas yang ditawarkan perusahaan.

Salah satu tujuan utama perusahaan adalah meningkatkan nilai perusahaan (Sudana, 2011:7). Nilai perusahaan merupakan persepsi investor terhadap tingkat keberhasilan perusahaan terkait harga saham (Sujoko dan Soebiantoro, 2007). Memaksimalkan nilai perusahaan sama dengan memaksimalkan nilai sekarang dari arus kas atau arus pendapatan yang diharapan dan telah diterima oleh investor pada masa yang akan datang (Sudana, 2011; 8). Investor akan menilai perusahaan yang baik adalah perusahaan yang memiliki sumber daya yang melimpah. Perusahaan dengan nilai yang tinggi merupakan suatu perusahaan dengan posisi keuangan yang baik, demikian pula sebaliknya.

Berdirinya sebuah perusahaan tidak terlepas dari tujuan untuk menciptakan nilai bagi pemiliknya, dengan cara memaksimumkan kekayaan pemegang saham. Semakin tinggi nilai perusahaan menggambarkan semakin sejahtera pula pemiliknya (Wahyudi dan Pawestri, 2006). Nilai perusahaan tercermin dari harga sahamnya. Mardiyati et al (2012) berpendapat bahwa nilai perusahaan yang go public di pasar modal tercermin dalam harga saham perusahaan, sedangkan nilai perusahaan yang belum go public nilainya terealisasi apabila perusahaan akan dijual, prospek perusahaan, risiko usaha, lingkungan usaha dan lain-lain.

Nilai perusahaan secara umum dapat diartikan sebagai harga yang bersedia dibayar oleh calon pembeli apabila perusahaan tersebut dijual (Husnan, 2000:7).Nilai perusahaan merupakan salah satu aspek yang cukup penting dalam investasi. Menurut 
Weston dan Copeland (1999:8) nilai dari saham kepemilikan merupakan indeks yang baik untuk mengukur tingkat efektifitas prestasi perusahaan.Nilai perusahaan dapat dipengaruhi oleh beberapa faktor,salah satunya adalah profitabilitas. Profit yang tinggi akan memberikan indikasi prospek perusahaan yang baik sehingga dapat memicu investor untuk ikut meningkatkan permintaan saham, selanjutnya dengan permintaan saham yang meningkat akan menyebabkan nilai perusahaan meningkat (Soliha, 2002) dalam Susanti (2010).

Perusahaan sub sektor lembaga pembiayaan merupakan salah satu lembaga yang saat ini mengalami perkembangan dan menjadi perhatian banyak investor untuk menanamkan modalnya dan memiliki peluang yang lebih besar untuk terus berkembang. Pertumbuhan penduduk yang besar menjadi penopang pertumbuhan pendapatan. Indonesia dengan penduduk lebih dari 250 juta orang adalah pasar yang menarik investor, Sehingga perusahaan sub sektor lembaga pembiayaan memiliki pengaruh yang cukup besar dalam memicu pertumbuhan ekonomi nasional.

Tabel 1.1

Price Book Value pada perusahaan PT. Mandala Multifinance, Tbk yang terdaftar di Bursa Efek Indonesia periode 2018-2020

\begin{tabular}{|c|c|}
\hline \multicolumn{2}{|c|}{ PT. Mandala Multifinance, Tbk } \\
\hline Tahun & PBV \\
\hline 2018 & 1.40 \\
\hline 2019 & 1.26 \\
\hline 2020 & 1.23 \\
\hline
\end{tabular}

Sumber: www.idx.co.id (Data diolah) 2021 
Berdasarkan Tabel 1.1 dapat ditarik kesimpulan bahwa PBV pada perusahaan PT. Mandala Multifinance, Tbk mengalami penurunan dari tahun 2018 sampai 2020.

Profitabilitas juga dapat memengaruhi nilai perusahaan. Besar kecilnya profitabilitas yang dihasilkan suatu perusahaan dapat memengaruhi nilai perusahaan dengan melihat profitabilitas sebagai ukuran dan kinerja perusahaan yang ditunjukan dari laba yang dihasilkan oleh perusahaan. Dengan melihat laba yang dihasilkan suatu perusahaan, jika perusahaan mampu membuatkan laba yang meningkat, hal itu mengindikasikan perusahaan tersebut mampu berkinerja dengan baik sehingga dapat menciptakan tanggapan yang positif dari investor dan juga meningkatkan harga saham dari perusahaan tersebut. Adapun laba yang dihasilkan perusahaan berasal dari penjualan produk dan investasi yang dilakukan oleh perusahaan. Laba yang dihasilkan perusahaan berasal dari penjualan produk dan investasi yang dilakukan oleh perusahaan. Perusahaan yang memiliki profitabilitas yang tinggi menunjukan bahwa perusahaan tersebut mengelola kekayaan perusahaan secara efektif dan efisien dalam memperoleh laba setiap periode (Horne dan Wachowicz dalam Rudangga dan Sudiarta, 2016). Menurut Husnan (2002:56) profitabilitas adalah hasil bersih dari berbagai kebijaksanaan dan keputusan yang diterapkan oleh sebuah perusahaan. Selain dari itu, profitabilitas didefinisikan sebagai kemampuan perusahaan menghasilkan laba dari penjualan barang atau jasa yang diproduksinya. Nilai dari suatu perusahaan dipengaruhi oleh besar kecilnya profitabilitas yang dihasilkan oleh perusahaan tersebut, karena semakin besarnya profitabilitas akan membuat nilai perusahaan semakin tinggi dan membuat investor berani berinvestasi di perusahaan tersebut. Adapun penelitian sebelumnya menurut Nurmayasari (2012), Prastika (2012) 
dan Almajali (2012) menemukan bahwa profitabilitas berpengaruh positif terhadap nilai perusahaan Pengaruh tersebut disebabkan terjadinya sentimen positif para investor, sehingga mengakibatkan harga saham naik dan membuat nilai perusahaan meningkat (Kusuma,dkk., 2012), namun hal sebaliknya ditemukan dalam penelitian Suranta dan Pranata (2003) dan Herawati (2012) bahwa profitabilitas secara signifikan berpengaruh negatif terhadap nilai perusahaan.

Mengingat dalam penelitian sebelumnya terdapat kesenjangan penelitian, maka peneliti tertarik untuk melakukan penelitian ulang diperusahaan sub sektor lembaga pembiayaan tentang profitabilitas terhadap nilai perusahaan sehingga peneliti memilih judul “ Pengaruh Profitabilitas Terhadap Nilai Perusahaan Pada PT. Mandala Multifinance, Tbk"

\section{RUMUSAN MASALAH}

Berdasarkan latar belakang yang telah diuraikan sebelumnya, maka yang menjadi rumusan masalah dalam penelitian ini adalah:

Apakah profitabilitas berpengaruh terhadap nilai perusahaan pada PT. Mandala Multifinance, Tbk .

\section{TUJUAN DAN KEGUNAAN PENELITIAN}

\section{TUJUAN PENELITIAN}

Untuk mengetahui dan menganalis pengaruh profitabilitas terhadap nilai perusahaan pada PT. Mandala Multifinance, Tbk. 


\section{KEGUNAAN PENELITIAN}

a. Bagi perusahaan yang diteliti, diharapkan mampu memberikan informasi dan memberikan gambaran dalam upaya peningkatan kinerja perusahaan.

b. Bagi investor, penelitian ini dapat digunakan sebagai informasi dan masukan yang diharapkan dapat memberikan sumbangan pemikiran serta dapat dijadikan ajuan pertimbangan dalam mengambil keputusan investasi di Bursa Efek Indonesia.

c. Bagi peneliti selanjutnya, diharapkan dapat dijadikan referensi dan rujukan dalam melakukan penelitian-penelitian selanjutnya yang membahas topik dan permasalahan yang sama dengan cara pandang yang berbeda.

\section{TINJAUAN PUSTAKA}

\section{Pasar Modal}

\section{a. Pengertian Pasar Modal}

Pengertian pasar dalam arti sempit adalah tempat para penjual dan pembeli bertemu untuk melakukan transaksi. Pembeli dan penjual langsung bertemu untuk melakukan transaksi dalam suatu tempat yang disebut dengan pasar. Dalam pengertian yang luas, pasar merupakan tempat melakukan transaksi dan pembeli. Dalam pengertian ini, antara penjual dan pembeli tidak harus bertemu dalam suatu tempat secara langsung (Kasmir, 2004: 193). Hubungan antara keduanya dapat dilakukan dengan menggunanakan sarana informasi yang ada seperti internet, telepon seluler ataupun sarana-sarana yang lain. 
Secara umum, pengertian pasar modal adalah suatu tempat bertemunya para penjual dan pembeli saham untuk melakukan suatu transaksi dalam rangka memperoleh modal. Penjual dalam pasar modal ialah suatu perusahaan yang membutuhkan modal (emiten), dengan cara menjual efek-efek. Pembeli atau investor adalah pihak yang ingin membeli modal pada perusahaan yang menurutnya akan mendatangkan keuntungan. Pasar modal juga dikenal dengan nama bursa efek (Kasmir, 2004: 193).

Menurut Undang-Undag Pasar Modal No. 8 tahun 1995, pasar modal adalah kegiatan yang bersangkutan dengan penawaran umum dan perdagangan efek, perusahaan publik yang berkaitan dengan efek yang diterbitkannya, serta lembaga dan profesi yang berkaitan dengan efek.

Pasar modal merupakan pasar untuk berbagai instrumen keuangan jangka panjang yang bisa diperjualbelikan, baik dalam bentuk utang ataupun modal sendiri. Pasar modal merupakan juga pasar untuk untuk surat berharga jangka panjang. Sedangkan, pasar uang merapakan pasar surat berharga jangka pendek. Baik pasar modal maupun pasar uang merupakan bagian dari pasar keuangan (Sudarsono, 2007: 184). Instrumen keuangan yang diperjualbelikan pada pasar modal adalah saham, obligasi, waran, right, obligasi konvertabel, dan berbagai produk turunan seperti opsi dan lain-lain. Sedangkan, yang diperjualbelikan di antaranya adalah Surat Bank Indonesia (SBI), Surat Berharga Pasar 
Uang (SBPU), Commercial Paper Notes, Call Monery, Repurchase Agreement, Banker's Acceptence, Treasury Bill dan lain-lain.

\section{Nilai Perusahaan}

\section{a. Pengertian Nilai Perusahaan}

Husnan (2006:7) menyatakan bahwa "Nilai perusahaan merupakan harga yang bersedia dibayar oleh calon pembeli apabila perusahaan tersebut dijual". Dengan demikian nilai perusahaan meningkat apabila harga saham meningkat sehingga meningkatnyanilai perusahaan dapat meningkatkan nilai saham pemegang saham. Weston dan Copeland (1997:191) menyatakan bahwa ada banyak metodologi untuk menilai perusahaan. Salah satunya yang akan kita perhatikan adalah arus kas yang akan didiskontokan.

Nilai perusahaan dipandang sebagai sesuatu yang sangat penting karena dengan nilai perusahaan yang tinggi maka akan diikuti dengan tingginya kemakmuran pemegang saham. Nilai perusahaan yang tinggi dapat meningkatkan kemakmuran bagi para pemegang saham, sehingga para pemegang saham akan menginvestasikan modalnya kepada perusahaan tersebut (Fenandar dan Surya, 2012). Semakin tinggi harga saham maka semakin tinggi nilai perusahaan, semakin tinggi nilai perusahaan maka akan semakin tinggi juga kemakmuran para pemilik saham.

Menurut Tandelilin (2001) dalam penilaian saham dikenal ada tiga jenis nilai, yaitu nilai buku, nilai pasar dan nilai intrinsik. Menurut Rahayu 
(2007) dalam Martalina (2011), beberapa konsep nilai yang menjelaskan nilai suatu perusahaan adalah nilai nominal, nilai pasar, nilai intrinsik, nilai buku dan nilai likuidasi.

1. Nilai nominal adalah nilai yang tercantum secara formal dalam anggaran dasar perseroan, disebutkan secara eksplisit dalam neraca perusahaan dan juga ditulis jelas dalam surat saham kolektif.

2. Nilai pasar adalah harga yang terjadi dari proses tawar menawar di pasar saham. Nilai ini hanya bisa ditentukan jika saham perusahaan dijual di pasar saham. Nilai pasar merupakan nilai perusahaan, karena nilai perusahaan yang dapat memberikan kemakmuran pemegang saham secara maksimum apabila harga saham perusahaan meningkat.

3. Nilai intrinsik merupakan konsep yang paling abstrak, karena mengacu pada perkiraan nilai riil suatu perusahaan.

4. Nilai buku adalah nilai perusahaan yang dihitung dengan dasar konsep akuntansi. Secara sederhana dihitung dengan membagi selisih antara total aktiva dan total utang dengan jumlah saham yang beredar.

5. Nilai likuidasi adalah nilai jual seluruh aset perusahaan setelah dikurangi semua kewajiban yang harus dipenuhi. Nilai sisa merupakan bagian para pemegang saham.

Ada beberapa cara dalam mengukur nilai perusahaan, diantaranya, yaitu Price to Earning Ratio (PER), Price to Book Value (PBV), dan Tobins'Q. PER merupakan besarnya perbandingan antara harga saham 
perusahaan dengan keuntungan yang diperoleh oleh para pemegang saham.PBV Untuk perusahaan-perusahaan yang berjalan dengan baik, umumnya rasio ini mencapai diatas satu, yang menunjukkan bahwa nilai pasar saham lebih besar dari nilai bukunya. Semakin besar rasio PBV semakin tinggi perusahaan dinilai oleh para pemodal relatif dibandingkan dengan dana yang telah ditanamkan di perusahaan. Tobin's $Q$ dihitung dengan membandingkan rasio nilai pasar saham perusahaan dengan nilai buku ekuitas perusahaan.Pada penelitian ini, untuk mengukur nilai perusahaan menggunakan Price to Book Value (PBV), rasio ini berfungsi untuk mengidentifikasi saham yang harganya wajar, terlalu rendah (Undervalued) dan terlalu tinggi (Overvalued).Cara ini mengaitkan rasio PBV dengan nilai intrinsik saham yang diperkirakan berdasarkan model penilaian saham.

Price to Book Value (PBV) adalah suatu rasio yang sering digunakan untuk menentukan nilai perusahaan dan mengambil keputusan investasi dengan cara membandingkan harga saham per saham dengan nilai buku perusahaan (Andinata, 2010).Harga pasar per saham merupakan harga yang disepakati oleh penjual dan pembeli pada saat terjadinya transaksi per lembar saham. Sedangkan untuk nilai buku per saham merupakan harga pada saat aktiva tersebut diperoleh (nilai historis) per lembar saham (Andinata, 2010). 


\section{b. Pengukuran Nilai Perusahaan}

Menurut Brigham dan Houston (2010:112), menyatakan nilai perusahaan dapat di ukur dengan price to book value (PBV). Komponen penting lain yang harus di perhatikan dalam analisis kondisi perusahaan adalah price to book value (PBV) yang merupakan salah satu variabel yang di pertimbangkan seorang investor dalam menentukan saham mana yang akan di beli. Untuk perusahaan-perusahaan yang berjalan dengan baik, umumnya rasio ini mencapai di atas satu, yang menunjukan bahwa nilai pasar saham lebiih besar dari nilai bukunya. Semakin besar rasio PBV semakin tinggi perusahaan dinilai oleh para pemodal relative di bandingkan dengan dana yang telah di tanamkan di perusahaan. Nilai perusahaan dapat di rumuskan sebagai berikut:

$$
\text { price to book value }=\frac{\text { Harga Pasar Per Saham }}{\text { Nilai Buku Persaham }}
$$

\section{Profitabilitas}

\section{a. Pengertian Profitabilitas}

Profitabilitas adalah hasil akhir dari sejumlah kebijakan dan keputusan manajemen perusahaaan (Brigham dan Gapenski, 2006). Dengan demikian dapat dikatakan bahwa profitabilitas perusahaan merupakan kemampuan perusahaan dalam menghasilkan laba bersih dari aktivitas yang dilakukan pada suatu periode akuntansi. Profitabilitas menurut Saidi (2004) dalam Martalina (2011) adalah kemampuan perusahaan dalam memperoleh laba. Para investor menanamkan saham 
pada perusahaan adalah untuk mendapatkan return, yang terdiri dari yield dan capital gain. Semakin tinggi kemampuan memperoleh laba, maka semakin besar return yang diharapkan investor, sehingga menjadikan nilai perusahaan menjadi lebih baik.

Profitabilitas merupakan kemampuan perusahaan memperoleh laba dalam hubungannya dengan penjualan, total aktiva atau dengan modal (ekuitas). Dalam hal ini dapat dijelaskan untuk mengetahui profitabilitas suatu perusahaan adalah sangat penting bagi investor maupun kreditor. Menurut Sartono (2001:122) profitabilitas adalah kemampuan perusahaan memperoleh laba dalam hubungannya dengan penjualan, total aktiva maupun modal sendiri. Sedangkan menurut Munawir (1995:31) dalam Martalina (2011) profitabilitas adalah kemampuan perusahaan dalam menghasilkan laba dalam periode tertentu. Dari kedua pengertian tersebut dapat disimpulkan bahwa yang dimaksud dengan profitabilitas adalah kemampuan perusahaan dalam menghasilkan laba selama periode tertentu yang dapat dihitung berdasarkan penjualan atau aktiva atau modal sendiri.

Menurut Munawar (1995) ada beberapa faktor yang mempengaruhi profitabilitas perusahaan, yaitu :

1. Jenis Perusahaan

Profitabilitas perusahaan akan sangat bergantung pada jenis perusahaan, jika perusahaan menjual barang konsumsi atau jasa 
biasanya akan memiliki keuntungan yang stabil dibandingkan dengan perusahaan yang memproduksi barang-barang modal.

2. Umur Perusahaan

Sebuah perusahaan yang telah lama berdiri akan lebih stabil bila dibandingkan dengan perusahaan yang baru berdiri. Umur perusahaan ini adalah umur sejak berdirinya perusahaan hingga perusahaan tersebut masih mampu menjalankan operasinya.

3. Skala Perusahaan

Jika skala ekonominya lebih tinggi, berarti perusahaan dapat menghasilkan produk dengan biaya yang rendah. Tingkat biaya rendah tersebut merupakan cara untuk memproleh laba yang diinginkan.

4. Harga Produksi

Perusahaan yang biaya produksinya relatif lebih murah akan memiliki keuntungan yang lebih baik dan stabil daripada perusahaan yang biaya produksinya tinggi.

Menurut Daga (2021) Produk yang mempunyai kualitas yang sama tetapi menetapkan harga yang relatif murah, akan memberikan nilai lebih tinggi kepada konsumennya.

5. Habitat Bisnis

Perusahaan yang bahan produksinya dibeli atas dasar kebiasaan (habitual basis) akan memperoleh kebutuhan lebih stabil dari pada non habitual basis. 
6. Produk yang Dihasilkan

Perusahaan yang bahan produksinya berhubungan dengan kebutuhan pokok biasanya penghasilan perusahaan tersebut akan lebih stabil daripada perusahaan yang memproduksi barang modal.

\section{b. Pengukuran Profitabilitas}

Menurut Sutrisno (2017:212), rasio profitabilitas dapat diukur dengan beberapa indikator yakni:

\section{1) Profit Margin}

Profit Margin merupakan kemampuan perusahaan untuk menghasilkan keuntungan dibandingkan dengan penjualan yang dicapai. Rumus yang bisa digunakan adalah sebagai berikut:

$$
\begin{gathered}
\text { Gross Profit Margin }=\frac{\text { laba kotor }}{\text { penjualan }} \times 100 \% \\
\text { Profit Margin }=\frac{\text { EAT }}{\text { penjualan }} \times 100 \% \\
\text { Net Profit Margin }=\frac{\text { EBIT }}{\text { penjualan }} \times 100 \%
\end{gathered}
$$

\section{2) Return On Asset (ROA)}

Return On Asset sering disebut juga sebagai rentabilitas economis merupakan ukuran kemampuan perusahaan dalam menghasilkan laba dengan semua aktiva yang dimiliki oleh perusahaan. Dalam hal ini laba yang dihasilkan adalah laba sebelum bunga pajak atau EBIT.

Return On Asset $=\frac{\text { EBIT }}{\text { Total aktiva }} \times 100 \%$ 


\section{3) Return On Equity}

Return On Equityini sering disebut juga dengan rate on Net Worth yaitu kemampuan perusahaan dalam menghasilkan keuntungan dengan modal sendiri yang dimiliki, sehingga ROE ini ada yang menyebut sebagai rentabilitas modal sendiri. Laba yang diperhitungkan adalah laba bersih setelah dipotong pajak atau EAT. Dengan demikian rumus yang digunakan adalah:

Return On Equity $=\frac{\text { EAT }}{\text { Modal sendiri }} \times 100 \%$

\section{4) Return On Investment}

Return On Investment merupakan kemampuan perusahaan untuk menghasilkan keuntungn yang akan digunakan untuk menutup investasi yang dikeluarkan. Laba yang digunakan untuk mengukur rasio ini adalah laba bersih setelah pajak atau EAT.

Return On Investment= $=\frac{\text { EAT }}{\text { Investasi }} \times 100 \%$

\section{5) Earning Per Share}

Kadang-kadang pemilik juga menginginkan data mengenai keuntungan yang diperoleh untuk setiap lembar sahamnya. Earning per share atau laba per lembar saham merupakan ukuran kemampuan perusahaan untuk menghasilkan keuntungan per lembar saham pemilik. Laba yang digunakan sebagai ukuran adalah laba bagi pemilik atau EAT.

$E P S=\frac{E A T}{\text { Jumlah lembar saham }}$ 


\section{Hubungan Profitabilitas Terhadap Nilai Perusahaan}

Semakin baik pertumbuhan profitabilitas berarti prospek perusahaan di masa depan dinilai semakin baik juga, artinya semakin baik pula nilai perusahaan dimata investor. Apabila kemampuan perusahaan untuk menghasilkan laba meningkat, maka harga saham juga akan meningkat (Husnan, 2001:317). Harga saham yang meningkat mencerminkan nilai perusahaan yang baik bagi investor. Suharli (2006) dalam Martalina (2011) menyatakan bahwa nilai pemegang saham akan meningkat apabila nilai perusahaan meningkat yang ditandai dengan tingkat pengembalian investasi yang tinggi kepada pemegang saham.

Tingkat pengembalian investasi kepada pemegang saham tergantung pada laba yang dihasilkan perusahaan. Oktaviani (2008) dalam Lifessy (2011) juga menyatakan bahwa dengan tingginya tingkat laba yang dihasilkan, berarti prospek perusahaan untuk menjalankan operasinya di masa depan juga tinggi sehingga nilai perusahaan yang tercermin dari harga saham perusahaan akan meningkat pula.

\section{Penelitian Terdahulu}

Adapun peneliti yang telah melakuakn penelitian terkait, antara lain sebagai berikut:

a. Penelitian yang dilakukan oleh Susanti (2010) dengan judul "Analisis Faktor-Faktor yang Berpengaruh terhadap Nilai Perusahaan, Studi Kasus pada Perusahaan Go Public yang Listed Tahun 2005-2008”. Hasil 
penelitian menunjukkan bahwa profitabilitas berpengaruh positif dan signifikan terhadap nilai perusahaan.

b. Penelitian yang dilakukan oleh Allan Fazri Almamfaozi (2015) dengan judul "pengaruh Kebijakan Pendanaan, Kebijakan Investasi, Kebijakan Deviden dan Profitabilitas Terhadap Nilai Perusahaan (studi pada perusahaan Manufaktur yang terdaftar di Bursa Efek Indonesia selama periode tahun 2010 sampai 2014)". Hasil penelitian menunjukkan bahwa profitabilitas berpengaruh positif dan signifikan terhadap nilai perusahaan.

c. Penelitian yang dilakukan oleh Soliha \& Taswan (2002) dengan judul "Pengaruh Kebijakan Hutang terhadap Nilai Perusahaan serta Beberapa Faktor yang Mempengaruhinya". Hasil penelitian menunjukkan bahwa profitabilitas berpengaruh signifikan dan positif terhadap nilai perusahaan.

\section{B. KERANGKA PIKIR}

\section{Gambar 2.1 Kerangka Pikir}

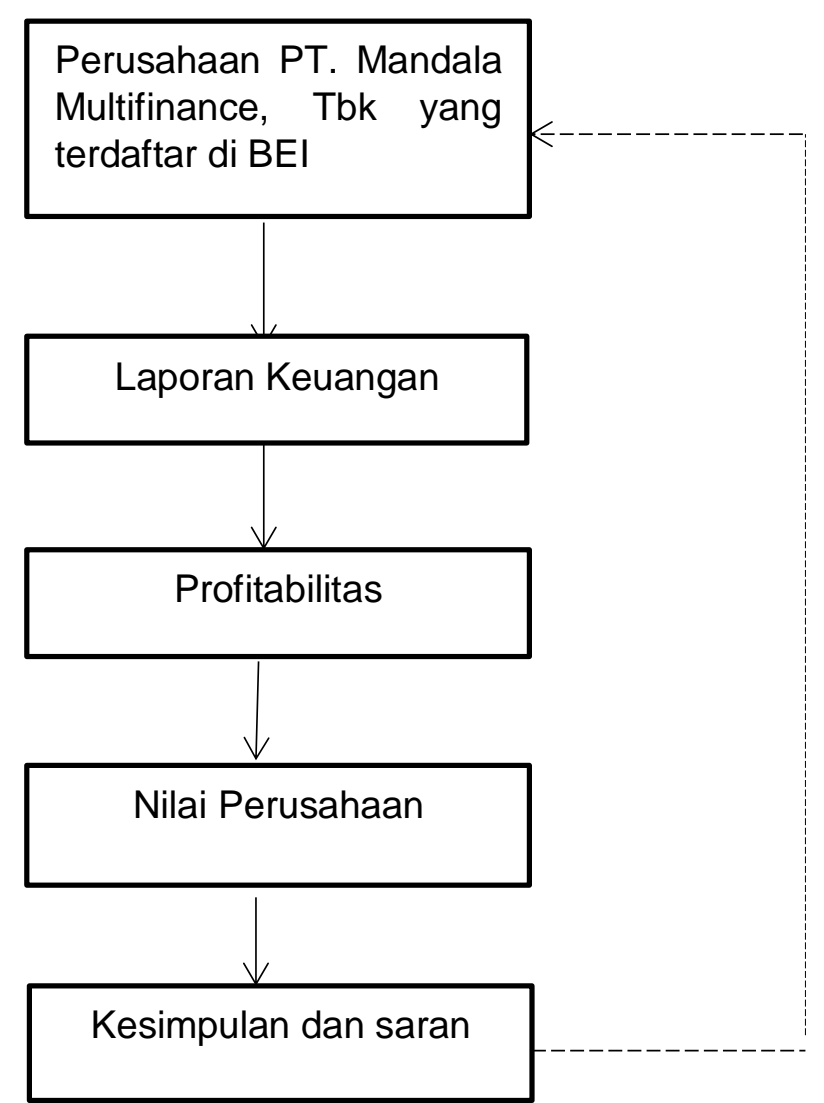




\section{Keterangan:}

Gambar 2.1 mengambarkan peneliti melakukan penelitian pada perusahaan PT. Mandala Multifinance, Tbk. Dimana penulis ingin mengetahui pengaruh profitabilitas terhadap nilai perusahaan pada PT. Mandala Multifinance, Tbk. Sehingga diharapkan penulis dapat mengambil kesimpulan dan memberikan saran kepada investor dalam mempertimbangkan untuk melakukan investasi di Bursa Efek Indonesia.

\section{METODE PENELITIAN}

\section{A. LOKASI PENELITIAN}

Penelitian ini dilakukan di Galeri Investasi Institut Bisnis dan Keuangan Nitro Makassar yang berlokasi di Jalan Professor Abdurrahman Basalamah No. 101, Kota Makassar. Waktu yang dibutuhkan untuk melakukan penelitian ini kurang lebih 1 (Satu) bulan.

\section{B. JENIS DAN SUMBER DATA}

\section{Jenis Data}

Jenis data yang digunakan dalam penelitian ini adalah Data Kuantitatif yaitu data yang diperoleh berupa laporan keuangan dan ringkasan laporan keuangan yang ada kaitannya dengan penelitian ini.

\section{Sumber Data}

Sumber data yang digunakan dalam penelitian ini adalah data sekunder yaitu data yang tidak langsung didapatkan dari objek penelitian tapi diperoleh dalam bentuk data yang telah dikumpulkan, diolah dan 
dipublikasikan oleh pihak lain yaitu Bursa Efek Indonesia (BEI) melalui Galeri Investasi IBK Nitro Makassar.

\section{TEKNIK PENGUMPULAN DATA}

Teknik pengumpulan data yang di gunakan dalam penelitian ini meliputi:

1. Penelitian kepustakaan (Library research), Yaitu penelitian yang dilakukan dengan menggunakan beberapa teori dari literatu-literatur dan jurnal serta situs-situs internet berhubungan dengan masalah yang dibahas dalam penelitian ini.

2. Penelitian dokumentasi (Documentation research), yaitu penelitian yang dilakukan dengan menggunakan dokumen-dokumen lainnya yang berkaitan dengan penelitian ini.

\section{POPULASI DAN SAMPEL}

\section{Populasi}

Populasi yang di gunakan dalam penelitian ini adalah perusahaan sub sektor lembaga pembiayaan dan komponennya yang terdaftar di Bursa Efek Indonesia sebanyak 19 perusahaan.

\section{Sampel}

Sampel yang digunakan dalam penelitian ini adalah perusahaan pada sub sektor lembaga pembiayaan yang terdaftar di Bursa Efek Indonesia. Peneliti menggunakan teknik pengambian sampel berfokus pada teknik purposive sampling. Menurut Sugiyono (2018:85) sampling purposive adalah teknik penentuan sampel dengan pertimbangan tertentu. Selain itu, purposive sampling dilakukan dengan cara mengambil subjek yang didasarkan atas 
adanya tujuan tertentu. Kriteria dalam pemilihan sampel yang akan diteliti adalah sebagai berikut:

a. Perusahaan mengungkapkan data yang diperlukan dalam penelitian secara lengkap selama periode 2018-2020.

b. Perusahaan yang memperoleh laba priode tahun 2018-2020.

c. Perusahaan yang telah menerbitkan laporan keuangan terutama priode 2018-2020.

Berdasarkan kriteria pengambilan sampel tersebut, dari 19 (Sembilan belas) jumlah populasi perusahaan pada indeks sub sektor lembaga pembiayaan, terdapat 7 (Tujuh) perusahaan pada indeks sub sektor lembaga pembiayan yang menjadi sampel dalam penelitian ini. Adapun perusahaan yang menjadi sampel dalam penelitian ini dapat dilihat pada tabel sebagai berikut:

Tabel 3.1

Daftar Sampel Perusahaan sub sektor lembaga pembiayaan yang Terdaftar di BEI Tahun 2018-2020

\begin{tabular}{|l|l|l|}
\hline No. & Kode Efek & \multicolumn{1}{c|}{ Nama Emiten } \\
\hline 1 & ADMF & Adira Dinamika Multi Finance Tbk \\
\hline 2. & BBLD & Buana Finance Tbk \\
\hline 3. & BFIN & BFI Finance Indonesia Tbk \\
\hline 4. & CFIN & Clipan Finance Indonesia Tbk \\
\hline 5. & DEFI & Danasupra Erapacific Tbk \\
\hline 6. & BPFI & Batavia Prosperindo Finance Tbk \\
\hline 7. & FUJI & Fuji Finance Indonesia Tbk \\
\hline \multicolumn{2}{|c|}{ Sumber: www.idx.co.id (diolah) }
\end{tabular}

\section{E. DEFINISI OPERASIONAL PERUSAHAAN}

Definisi operasional penelitian merupakan batasan-batasan yang dipakai untuk menghindari interpretasi yang lain terhadap variabel yang diteliti, sebab 
variabel di dalam penelitian adalah merupakan sasaran dari objek penelitian. Pada penelitian ini terdapat dua variabel yaitu variabel independen $(X)$ dan dependen ( $\mathrm{Y})$. Adapun definisi operasional masing-masing variabel yang digunakan dalam penelitian ini sebagai berikut:

\section{Profitabilitas $(X)$}

Profitabilitas merupakan kemampuan perusahaan yang tergolong dalam sub sektor pertambangan batu bara dalam menghasilkan laba dengan menggunakan total aset yang ada dan setelah biaya-biaya modal.

$$
\text { Return On Asset }(\mathrm{ROA})=\frac{\text { Laba setelah pajak }}{\text { Total } \text { Asset }} \times 100 \%
$$

\section{Nilai Perusahaan $(Y)$}

Nilai Perusahaan adalah harga pasar yang dilihat para investor maupun calon investor sebagai persepsi untuk keberhasilan suatu usaha. Nilai perusahaan dalam penelitian ini menggunakan Price to Book Value (PBV)yaitu perbandingan antara harga pasar saham dengan nilai buku per saham. Rumus Price to Book Value sebagai berikut:

$$
\mathrm{PBV}=\frac{\text { Laba Bersih Setelah Pajak }}{\text { Nilai Buku Per Saham }} \times 100
$$

\section{F. ANALISIS DATA}

\section{Uji Asumsi Klasik}

a. Uji Normalitas

Pengujian normalitas data penelitian adalah menguji apakah dalam model statistik variabel-variabel penelitian terdistribusi normal atau tidak. Model regresi yang baik adalah memiliki distribusi normal atau mendekati 
normal atau tidak, maka dapat dilakukan dengan cara normal P-Plot. Adapun dasar pengambilan keputusan:

1. Jika data menyebar disekitar garis diagonal dan mengikuti arah diagonal atau grafik histogramnya menunjukan pola distribusi normal, maka model regresi memenuhi asumsi normalitas.

2. Jika data menyebar jauh dari garis diagonal dan/atau tidak menunjukan pola distribusi normal maka model regresi tidak memenuhi asumsi normalitas.

b. Uji Multikolinearitas

Uji Multikolinearitas bertujuan untuk menguji apakah dalam persamaan regresi ditemukan adanya korelasi antar variabel bebas. Dalam model regresi yang baikseharusnya tidak terjadi korelasi diantara variabel bebas. Multikolinearitas akan menyebabkan koefisien regresi bernilai kecil dan standar error bernilai besar sehingga pengujian variabel bebas secara individu akan menjadi tidak signifikan. Untuk menguji ada tidaknya gejala multikolinearitas antara variabel independen digunakan Varience Inflation Factor (VIF). Apabila VIF $>10$, terjadi multikolinearitas. Sebaliknya jika VIF $<10$, tidak terjadi multikolinearitas.

c. Uji Autokorelasi

Uji Autokorelasi adalah untuk menguji apakah dalam suatu model regresi linear ada korelasi antara penganggu periode t dengan kesalahan pada periode $\mathrm{t}-1$ (sebelumnya). Jika terdapat korelasi, maka dinamakan ada problem autokorelasi. Model regresi yang baik adalah regresi yang 
bebas dari autokorelasi salah satu cara yang dapat digunakan untuk mendeteksi ada tidaknya autokorelasi adalah uji Durbin-Watson (D-W test). Cara pengujiannya dengan membandingkan nilai Durbin-Watson (d) dengan dl atau du tertentu atau dengan melihat table Durbin Watson yang telah ada klasifikasinya untuk menilai perhitungan (d) yang diperoleh akibat dari adanya autokorelasi dalam regresi, koefisien regresi diperoleh menjadi tidak efisien, artinya tingkat kesalahannya menjadi sangat besar dan koefisien regresi menjadi tidak stabil. Untuk menguji ada tidaknya autokorelasi dari data residual terlebih dahulu dihitung nilai satitistik Durbin-Watson (D-W test) sebagai berikut:

1) Jika d-w $<d l$, berarti terdapat autokorelasi positif.

2) Jika $d-w>(2-d l)$, berartit terdapat autokorelasi negative

3) Jika du < d-w (2-dl), berarti tidak terdapat autokorelasi.

4) Jika $d l<d-w<d u$ atau (2-du), berarti tidak dapat di simpulkan.

d. Uji Heteroskedastistas

Uji Heteroskedastistas bertujuan untuk menguji apakah dalam model regresi terjadi ketidaksamaan varian dari residual atau pengamatan ke pengamatan lain. Salah satu cara untuk mendeteksi ada atau tidaknya heteroskedastistas adalah melihat grafik plot antara nilai prediksi variabel tidak bebas (ZPRED) dengan residualnya (SRESID). Deteksi ada atau tidaknya pola tertentu pada grafik Scatterplot. dengan dasar analisisnya sebagai berikut: 
1. Jika ada pola tertentu, seperti titik-titik yang ada membentuk pola tertentu yang teratr (bergelombang. melebar kemudian menyempit) maka mengidikasikan telah terjadi heteroskedastisitas.

2. Jika tidak ada pola yang jelas, serta titik-titik menyebar diatas dan dibawah angka 0 pada sumbu $\mathrm{Y}$, maka tidak terjadi heteroskedastisitas.

\section{Analisis Regresi Linear Sederhana}

Analisis regresi linear sederhana adalah sebuah metode pendekatan untuk pemodelan hubungan antara satu variabel dependen dan satu variabel independen. Dalam regresi, variabel independen menerangkan variabel dependennya. Dalam analisis regresi sederhana, hubungan antar variabel bersifat linear, dimana perubahan pada variabel $\mathrm{X}$ akan diikuti oleh perubahan Variabel $\mathrm{Y}$ secara tetap. Sementara pada hubungan non linear, perubahan variabel $\mathrm{X}$ tidak diikuti variabel Y secara proposional.

Model regresi linear sederhana sebagai berikut:

$$
\begin{aligned}
& Y=a+b x \\
& \text { Keterangan: } \\
& Y \quad=\text { Variabel dependen } \\
& a \quad=\text { konstanta } \\
& b \quad=\text { Koefisien regresi }
\end{aligned}
$$




\section{Uji Hipotesis (Uji t Partsial)}

Untuk menguji hipotesis tentang kekuatanvariabel independen terhadap variabel dependen, maka pada penelitian ini menggunakan Uji statistic t (parsial) yang menunjukan seberapa jauh Uji-t digunakan untuk melihat pengaruh variabel independen. Uji t digunakan untuk menguji signifikan pengaruh variabel independen secara pasrsial terhadap variabel dependen.

Signifikan atau tidaknya pengaruh variabel dependen dilihat dari nilai profitabilitas (nilai sig). dari t rasio masing-masing variabel independen pada taraf uji $a=5 \%(0,05)$.

\section{Koefisien Korelasi dan Koefisien Determinasi}

Nilai Koefisien Korelasi (R) menunjukan seberapa besar dengan variabel dependen. Koefisien Korelasi dikatakan kuat apabila diatas 0,5 mendekati 1.

Koefisien determinasi ( $R$ square) menunjukan seberapa besar variabel independen menjelaskan variabel dependennya. Apabila nilai $\mathrm{R}$ square makin mendekati satu, maka variable-variabel independennya telah memberikan variasi variabel dependen.

\section{SIMPULAN}

Berdasarkan hasil penelitian dan pembahasan yang telah disajikan pada bab-bab sebelumnya, maka dapat diambil kesimpulan sebagai berikut:

Berdasarkan uji secara parsial (Uji t) antara profitabilitas terhadap nilai perusahaan, diperoleh hasil bahwa profitabilitas berpengaruh signifikan positif terhadap nilai perusahaan. 


\section{DAFTAR PUSTAKA}

Alamsyah, S. (2017). Pengaruh Profitabilitas Terhadap Nilai Perusahaan, Relevansi Nilai Informasi Akuntansi, Keputusan Investasi, Kebijakan Dividen Sebagai Variabel Intervening (Studi Empiris Pada Perusahaan Indeks Kompas 100 Periode 2010-2013). Competitive Jurnal Akuntansi Dan Keuangan, 1(1), 136-161.

Ayu, D. P., \& Suarjaya, A. G. (2017). Pengaruh profitabilitas terhadap nilai perusahaan dengan corporate social responsibility sebagai variabel mediasi pada perusahaan pertambangan. E-Jurnal Manajemen Unud, 6(2), 1112-1138.

Daga, R. (2021). PENGARUH KEPERCAYAAN DAN KEPUASAN TERHADAP KOMITMEN NASABAH PADA PT. BANK RAKYAT INDONESIA (Persero) TbK. UNIT CITRA SUDIANG MAKASSAR.

Ernawati, D., \& Widyawati, D. (2015). Pengaruh profitabilitas, leverage dan ukuran perusahaan terhadap nilai perusahaan. Jurnal IImu dan Riset Akuntansi (JIRA), 4(4).

Hermuningsih, S. (2012). Pengaruh profitabilitas, size terhadap nilai perusahaan dengan sruktur modal sebagai variabel intervening. Jurnal siasat bisnis, 16(2).

Hermuningsih, S. (2013). Pengaruh profitabilitas, growth opportunity, struktur modal terhadap nilai perusahaan pada perusahaan publik di Indonesia. Buletin ekonomi moneter dan perbankan, 16(2), 127-148.

Lubis, I. L., Sinaga, B. M., \& Sasongko, H. (2017). Pengaruh profitabilitas, sruktur modal, dan likuiditas terhadap nilai perusahaan. Jurnal aplikasi bisnis dan manajemen (JABM), 3(3), 458-458. 
Nofrita, R. (2013). Pengaruh Profitabilitas terhadap Nilai Perusahaan dengan Kebijakan Deviden sebagai Variabel Intervening (Studi Empiris pada Perusahaan Manufaktur yang Terdaftar di BEI). Jurnal Akuntansi, 1(1).

Puspitaningtyas, Z. (2017). Efek Moderasi Kebijakan Dividen Dalam Pengaruh Profitabilitas Terhadap Nilai Perusahaan. Jurnal Akuntansi, Ekonomi Dan Manajemen Bisnis, 5(2), 173-180.

Wijaya, B. I., \& Sedana, I. P. (2015). Pengaruh profitabilitas terhadap nilai perusahaan (kebijakan dividen dan kesempatan investasi sebagai variabel mediasi). E-Jurnal Manajemen, 4(12).

Wulandari, D. R. (2013). Pengaruh Profitabilitas, Operating Leverage, Likuiditas terhadap nilai perusahaan dengan struktur modal sebagai intervening. Accounting Analysis Journal, 2(4). 